\title{
Synthesis, determination of the absolute configuration of tonkinelin, and inhibitory action with bovine heart mitochondrial complex I
}

Yasunao Hattori, ${ }^{\mathrm{a}, \mathrm{b}}$ Hiroyuki Konno, ${ }^{\mathrm{c}}$ Masato, Abe, ${ }^{\mathrm{d}}$ Hideto, Miyoshi, ${ }^{\mathrm{d}}$ Tetsuhisa Goto, ${ }^{\mathrm{a}, \mathrm{e}}$ and Hidefumi Makabe $^{\mathrm{f}_{*}}$

a Interdisciplinary Graduate School of Science and Technology, Shinshu University, 8304, Minami-minowa, Kami-ina, Nagano, 399-4598, Japan

batellite Venture Business Laboratory, Shinshu University, 3-15-1, Tokida, Ueda, Nagano, 386-8567, Japan ${ }^{\mathrm{c}}$ Department of Chemistry, Graduate School of Medical Science, Kyoto Prefectural University of Medicine, Kitaku, Kyoto 603-8334, Japan

${ }^{\mathrm{d} D i v i s i o n}$ of Applied Life Sciences, Graduate School of Agriculture, Kyoto University, Kita-shirakawa, Sakyo-ku, Kyoto 606-8502, Japan

${ }^{\mathrm{e}}$ Department of Bioscience and Biotechnology, Faculty of Agriculture, Shinshu University, 8304, Minami-minowa, Kami-ina, Nagano, 399-4598, Japan

${ }^{\mathrm{f}}$ Sciences of Functional Foods, Graduate School of Agriculture, Shinshu University, 8304 Minami-minowa, Kamiina, Nagano 399-4598, Japan

*Corresponding author. Tel. +81 26577 1630; fax +81 26577 1700, e-mail: makabeh@shinshu-u.ac.jp

Abstract: The first synthesis of two possible diastereomers of tonkinelin was achieved. By comparison of the optical rotation of two candidates of tonkinelin and the natural compound, it is suggested that the absolute configuration of natural tonkinelin is likely to be $(17 S, 18 S)$. The inhibitory activity of these compounds was examined with bovine heart mitochondrial NADH-ubiquinone oxidoreductase. These compounds showed remarkably weak inhibitory activity compared to ordinary acetogenins such as bullatacin.

Key words: annonaceous acetogenin, antitumor, mitochondrial complex I, stereoselective synthesis

\section{Introduction}

The annonaceous acetogenins, which are isolated from a number of plants of Annonaceae, have attracted much attention due to a wide variety of biological activities such as antitumoral, cytotoxic, antimalarial, immunosuppressive, pesticidal, and antifeedant activities. So far, more than 400 compounds have been isolated. ${ }^{1-}$

${ }^{3}$ Their unique structure is characterized by one or more tetrahydrofuran rings, together with a terminal $\gamma$-lactone 
moiety on C-35 or C-37 carbon chain. The inhibitory effect of acetogenin on mitochondrial NADH-ubiquinone oxidoreductase (complex I) is of particular importance since their diverse biological activities are thought to be attributable to this effect. On the basis of studies of the structure-activity relationship (SAR) carried out by Miyoshi and co-worker using systematically selected natural and synthetic acetogenins, the important structural factors responsible for the potent inhibition of mitochondrial complex I is the length of the alkyl spacer linking the two taxophores (i. e., the hydroxylated THF and the g-lactone rings). The optimal length of the spacer for inhibition is approximately 13 carbon atoms. ${ }^{4}$ Consequently, significant effort has been devoted toward the synthesis of acetogenins. ${ }^{5}$ Tonkinelin (1), which has a simple structure in the acetogenins, was isolated from Uvaria tonkinesis in 1996 by Y. Chen and a co-worker. ${ }^{6}$ This compound has two hydroxyl group at C-17 and C18 position, and possesses $\alpha, \beta$-unsaturated $\gamma$-lactone which can be seen in ordinary annonaceous acetogenins. The absolute configuration of $\mathbf{1}$ has not been reported yet. However, because the threo relative stereochemistry of the dihydroxyl part of $\mathbf{1}$ has been determined by Y. Chen and a co-worker, ${ }^{6}$ and the well known $(S)$ configuration of the secondary methyl group of the $\gamma$-lactone moiety ${ }^{7}$ was determined by the CD spectrum, ${ }^{6}$ it follows that the absolute stereochemistry of $\mathbf{1}$ is $(17 S, 18 S)$ or $(17 R, 18 R)$. Two possible structure, $\mathbf{1 a}$ and $\mathbf{1 b}$, would be difficult to differentiate by ${ }^{1} \mathrm{H}$ NMR or ${ }^{13} \mathrm{C}$ NMR spectroscopic data, since the two stereogenic regions, that is, the optically active dihydroxyl part and the $\gamma$-lactone moiety part are separated by a long carbon chain. X-lay analysis is also very difficult due to the waxy nature of this compound. Even ${ }^{1} \mathrm{H}$ NMR data of the both of $(R)$ - and $(S)$-bisMosher esters of $\mathbf{1 a}$ and/or $\mathbf{1 b}$ would not be differentiated because the $(R)$ - and $(S)$-bis-MTPA esters of $\mathbf{1 a}$ and $\mathbf{1 b}$ should give the same spectra. ${ }^{8}$ The optical rotation and/or melting point values would serve the clue to determine the absolute configuration. To establish the absolute configuration of tonkinelin (1) and evaluate its biological activity, we planned to synthesize the two candidates $\mathbf{1 a}$ and $\mathbf{1 b}$ (Figure. 1).

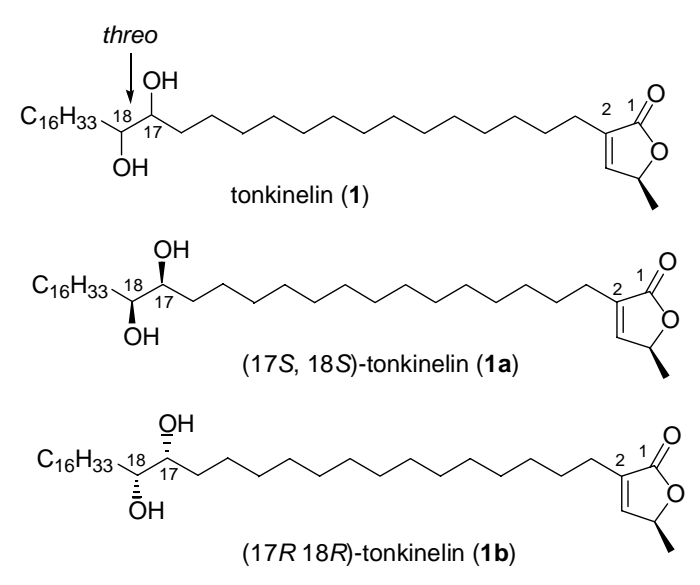

Figure 1. The possible structure of tonkinelin.

\section{Results and Discussion}




\subsection{Synthesis}

Our synthesis of dihydroxyl part of $\mathbf{1 a}$ is shown in Scheme 1. Iodide $\mathbf{2}$ was converted to allylic bromide $\mathbf{6}$ by a routine three-step reaction sequence: (i) alkynylation, (ii) reduction (LAH), (iii) bromination (NBS). Asymmetric dihydroxylation of 6 by the Sharpless procedure ${ }^{9}$ using AD mix $\alpha$ and spontaneous epoxidation afforded epoxy alcohol 7a, which showed 98 \% e.e. by a ${ }^{1} \mathrm{H}$ NMR analysis of the corresponding Mosher esters. When allyic chloride 5 was used in this reaction, spontaneous epoxidation did not proceed. The hydroxyl group of 7a was protected as methoxymethyl ether (MOM ether) to give compound 8a. Alkynylation of 8a with lithium acetylide, an ethylenediamine complex afforded 9a (Scheme 1).

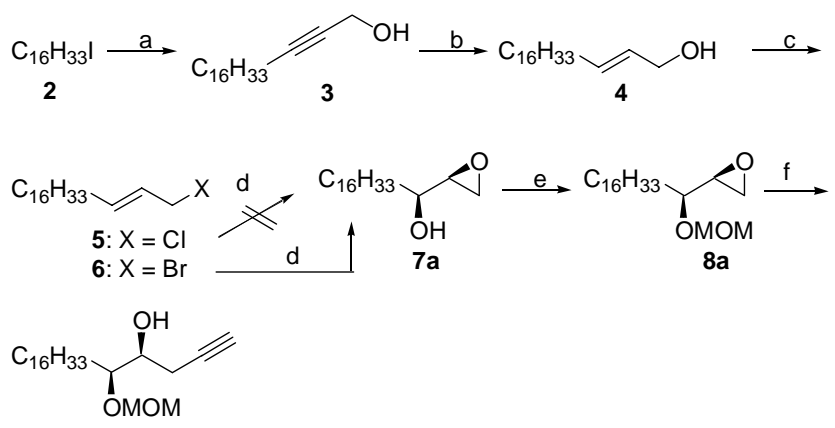

$9 \mathbf{a}$

Scheme 1. Synthesis of dihydroxyl part of $\mathbf{1 a}$.

Reagents and conditions: (a) propargyl alcohol, $n$-BuLi (55\%); (b) $\mathrm{LiAlH}_{4}, \mathrm{THF}$, reflux, (85\%); (c) $\mathrm{NBS}, \mathrm{PPh}_{3}$, $\mathrm{CH}_{2} \mathrm{Cl}_{2}$, (92\%); (d) AD mix $\beta, \mathrm{Me}_{2} \mathrm{SONH}_{2}$, (74\%); (e) $\mathrm{MOMBr}, i-\mathrm{Pr}_{2} \mathrm{NEt}, \mathrm{CH}_{2} \mathrm{Cl}_{2}$, (91\%); (f) lithium acetylide, an ethylene diamine complex (95\%).

$\gamma$-Lactone part 10 was prepared as we have reported before. ${ }^{10}$ Sonogashira cross-coupling reaction ${ }^{11}$ of 9a with 10 gave enyne 11a. Diimide reduction of 11a with $p$ - $\mathrm{TsNHNH}_{2}$ and sodium acetate in ethylene glycol diethyl ether afforded 12a. Finally, deprotection of the MOM ether with $\mathrm{BF}_{3} \bullet \mathrm{Et}_{2} \mathrm{O}$ afforded $\mathbf{1 a}$ (Scheme 2).

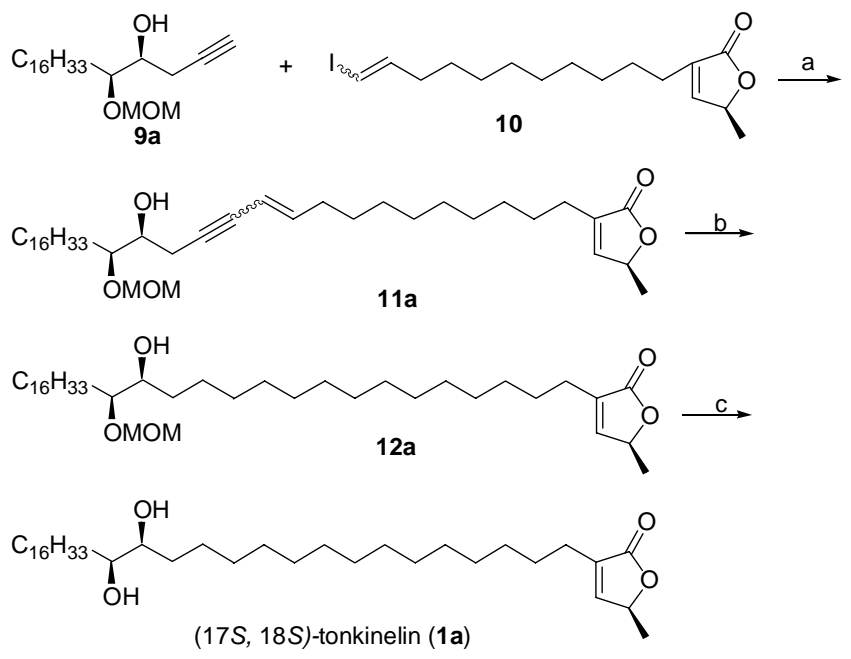

Scheme 2. Synthesis of (17S, 18S)-tonkinelin (1a). 
Reagents and conditions: (a) 5 mol\% of $\mathrm{Cl}_{2} \mathrm{Pd}\left(\mathrm{PPh}_{3}\right)_{2}, 10 \mathrm{~mol} \%$ of $\mathrm{CuI}, \mathrm{Et}_{3} \mathrm{~N}$ (65\%); (b) $p$ - $\mathrm{TsNHNH}_{2}, \mathrm{NaOAc}$ diethoxyethane (64\%); (c) $\mathrm{BF}_{3} \bullet \mathrm{Et}_{2} \mathrm{O}, \mathrm{Me}_{2} \mathrm{~S}$ (56\%).

Synthesis of $(17 R, 18 R)$-tonkinelin (1b) was achieved from $\mathbf{7 b}$ using AD mix $\beta$ from $\mathbf{6}$ as described in Scheme 2 (Scheme 3).

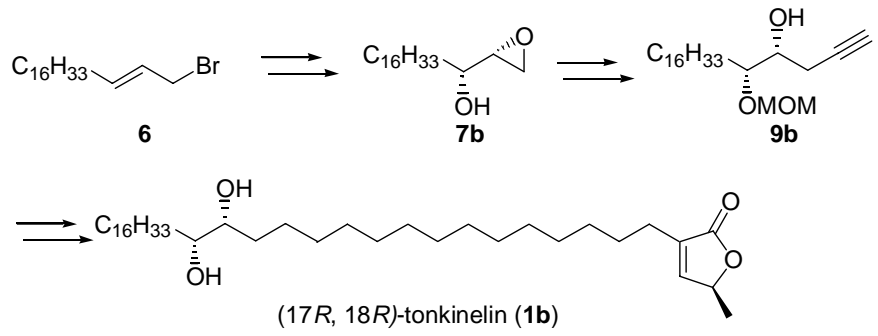

Scheme 3. Synthesis of (17R, 18R)-tonkinelin (1b).

The spectroscopic data $\left({ }^{1} \mathrm{H}\right.$ NMR, ${ }^{13} \mathrm{C}$ NMR, IR, and MS spectra) of synthetic $\mathbf{1 a}$ and $\mathbf{1 b}$ were in good agreement with those of natural ones. ${ }^{6}$ On the other hand, their optical rotations showed a clear difference. While the specific rotation of synthetic $1 \mathbf{a}\left([\alpha]_{\mathrm{D}}{ }^{18}=+11.6, c 0.14, \mathrm{CHCl}_{3}\right)$ is similar to the reported value of naturally occurring tonkinelin $\left([\alpha]_{\mathrm{D}}{ }^{16}=+14.49, c 0.07, \mathrm{CHCl}_{3}\right)$, that of $\mathbf{1 b}\left([\alpha]_{\mathrm{D}}{ }^{16}=+0.80, c 0.20, \mathrm{CHCl}_{3}\right)$ showed a much lower value. On the basis of these results, we suggested that the absolute configuration of natural tonkinelin is likely to be $1 \mathbf{a}$.

\subsection{Inhibitory action with bovine heart mitochondrial complex I}

Inhibitory effects of compounds $\mathbf{1 a}$ and $\mathbf{1 b}$ on bovine heart mitochondrial complex I were examined according to the previous method (Figure. 2). ${ }^{4}$ The $\mathrm{IC}_{50}$ values of $\mathbf{1 a}$ and $\mathbf{1 b}$ were 580 and $690 \mathrm{nM}$, respectively.
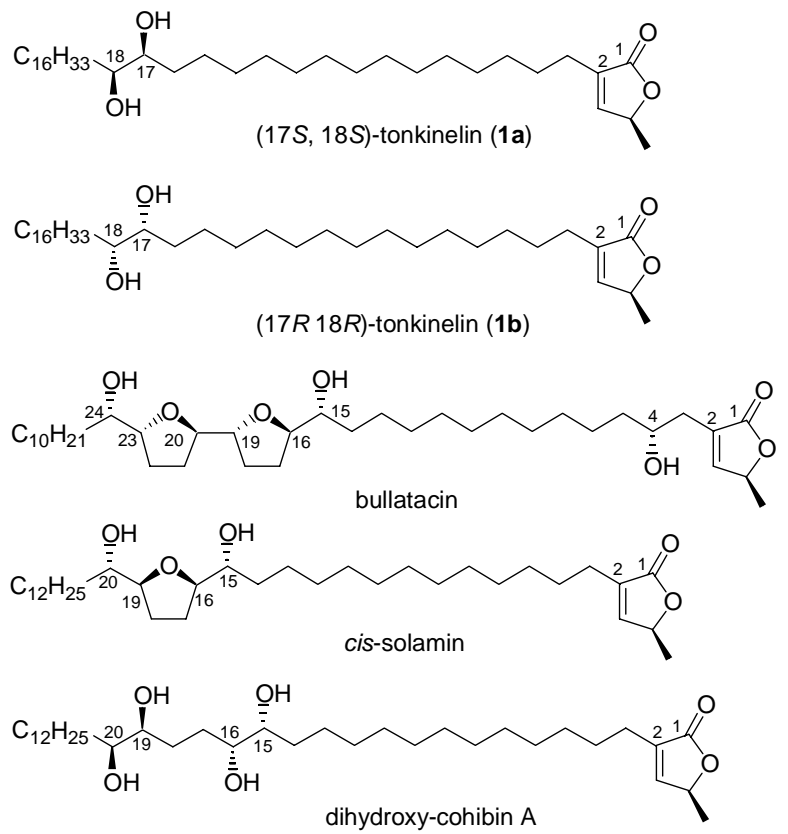

Figure 2. The structures of test compounds. 
Compounds 1a and 1b exhibited almost same inhibitory potency, indicating that the stereochemistry around the dihydroxyl moiety does not affect the inhibitory action. ${ }^{12}$ It is noteworthy that compared to potent natural ordinary acetogenins such as bullatacin $\left(\mathrm{IC}_{50}=0.83 \mathrm{nM}\right)^{4}$ and cis-solamin $\left(\mathrm{IC}_{50}=2.6 \mathrm{nM}\right),{ }^{13} \mathbf{1 a}$ and $\mathbf{1 b}$ are much weaker inhibitors of the enzyme. Further comparison with dihydroxy-cohibin-A $\left(\mathrm{IC}_{50}=20 \mathrm{nM}\right){ }^{14}$ which was synthesized by us, the inhibitory activity is quite weak. The extra hydroxy groups that can be seen in dihydroxycohibin A may play an analogous role with the ether oxygen(s) of THF derivatives. Another reason of the weak activity may be due to the length of the spacer. The spacer of $\mathbf{1 a}$ and/or $\mathbf{1 b}$ is longer (15 carbon atoms) than the optimal length (13 carbon atoms). Miyoshi and co-workers revealed that the decrease in the strength of the inhibitory effect caused by elongating the spacer from 13 carbons was much more drastic than that caused by shortening (Table 1$){ }^{4}$

\begin{tabular}{cc}
\multicolumn{2}{c}{ Table 1. Inhibitory activity of mitochondrial complex I } \\
\hline sample & $\mathrm{IC}_{50}(\mathrm{nM})$ \\
\hline 1a & 580 \\
1b & 690 \\
bullatacin & 0.83 \\
cis-solamin & 2.6 \\
dihydroxy-cohibin A & 20 \\
\hline
\end{tabular}

\section{Conclusion}

In conclusion, we have achieved a synthesis of (17S, 18S)-tonkinelin (1a), (17R, 18R)-tonkinelin (1b), and determined the absolute configuration of natural tonkinelin to be 1a. We also examined their inhibitory actions with bovine heart mitochondrial complex I. These compounds elicited much weaker activity compared to ordinary annonaceous acetogenins.

\section{Experimental}

4.1. General. All melting points were uncorrected. ${ }^{1} \mathrm{H}$ and ${ }^{13} \mathrm{C}$ NMR spectra were measured with a Bruker DRX 500 FT-NMR spectrometer in $\mathrm{CDCl}_{3}$ at 500 and $125 \mathrm{MHz}$, respectively. Chemical shifts were relative to tetramethylsilane as an internal standard. The coupling constants were given in Hz. Mass spectra were obtained on JEOL JMS-HX211A and JMS-HX110A mass spectrometer. IR spectra were recorded with JASCO FT-IR 480 Plus infrared spectrometer. Optical rotations were determined with a JASCO DIP-1000 polarimeter.

4.1.1. 2-Nonadecyn-1-ol (3). To a solution of propargyl alcohol (0.80 mL, $13 \mathrm{mmol})$ in THF was added $n$-BuLi (10 mL, $26 \mathrm{mmol}$ ) at $-20^{\circ} \mathrm{C}$. The mixture was stirred for $30 \mathrm{~min}$, and then iodide (3.87 $\mathrm{g}, 11 \mathrm{mmol}$ ) in HMPA (3.8 mL, $22 \mathrm{mmol}$ ) was added. The resultant mixture was stirred for $6 \mathrm{~h}$ at $0{ }^{\circ} \mathrm{C}$. The reaction was quenched with saturated aqueous $\mathrm{NH}_{4} \mathrm{Cl}(20 \mathrm{~mL})$ and extracted with EtOAc. The organic layer was washed with brine, dried over $\mathrm{MgSO}_{4}$, filtered, and concentrated. The residue was purified by silica gel column chromatography (hexane : AcOEt $=5: 1)$ to give $3(1.70 \mathrm{~g}, 55 \%)$ as a colorless solid. Mp 56-57 ${ }^{\circ} \mathrm{C}$; IR $(\mathrm{KBr}) v_{\max } \mathrm{Cm}^{-1}: 3184,2916,2848$, 2240, 1470, 1019, 716; ${ }^{1} \mathrm{H}$ NMR (500 MHz, $\mathrm{CDCl}_{3}$ ): $\delta=0.88$ (3H, t, $\left.J=6.9 \mathrm{~Hz}\right), 1.20-1.30$ (24H, m), 1.31-1.38 $(2 \mathrm{H}, \mathrm{m}), 1.47-1.53(2 \mathrm{H}, \mathrm{m}), 1.61(1 \mathrm{H}, \mathrm{s}), 2.21(2 \mathrm{H}, \mathrm{tt}, J=2.2,7.1 \mathrm{~Hz}), 4.25(2 \mathrm{H}, \mathrm{dt}, J=2.2,5.7 \mathrm{~Hz}) ;{ }^{13} \mathrm{C} \mathrm{NMR}$ 


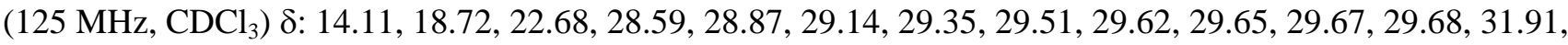
51.44, 78.20, 86.70; HREIMS $\left(\mathrm{M}^{+}\right)$: calcd. for $\mathrm{C}_{19} \mathrm{H}_{36} \mathrm{O}$, 280.2766; found, 280.2760.

4.1.2. (E)-2-Nonadecen-1-ol (4). To a suspension of $\mathrm{LiAlH}_{4}(470 \mathrm{mg}, 12 \mathrm{mmol}$ ) in THF was added acetylenic alcohol $3(1.70 \mathrm{~g}, 6.2 \mathrm{mmol})$ at $0{ }^{\circ} \mathrm{C}$. The mixture was stirred for $2 \mathrm{~h}$ under reflux. The reaction was quenched with water and extracted with EtOAc. The organic layer was washed with brine, dried over $\mathrm{MgSO}_{4}$, filtered, and concentrated. The residue was purified by silica gel column chromatography (hexane : AcOEt $=5: 1$ ) to give 4 (1.50 g, 85\%) as a colorless solid. Mp 44-46 ${ }^{\circ} \mathrm{C}$; IR (KBr) $v_{\max } \mathrm{cm}^{-1}$ : 3253, 3020, 2917, 2848, 1464, 1082, 961, 719; ${ }^{1} \mathrm{H}$ NMR (500 MHz, $\mathrm{CDCl}_{3}$ ): $\delta=0.88$ (3H, t, $\left.J=6.9 \mathrm{~Hz}\right), 1.20-1.30$ (26H, m), 1.31-1.39 (2H, m), 1.57 (1H, d, $J=7.1 \mathrm{~Hz}), 2.02-2.06(2 \mathrm{H}, \mathrm{m}), 4.08(2 \mathrm{H}, \mathrm{d}, J=5.1 \mathrm{~Hz}), 5.61-5.71(2 \mathrm{H}, \mathrm{m}) ;{ }^{13} \mathrm{C} \mathrm{NMR}\left(125 \mathrm{MHz}, \mathrm{CDCl}_{3}\right) \delta$ : 14.09, 22.68, 29.14, 29.35, 29.43, 29.50, 29.60, 29.65, 29.66, 29.69, 31.92, 32.21, 63.87, 128.82, 133.62; HREIMS ( $\left.\mathrm{M}^{+}\right)$: calcd. for $\mathrm{C}_{19} \mathrm{H}_{38} \mathrm{O}$, 282.2922; found, 282.2927.

4.1.3 (E)-1-Bromo-2-nonadecene (6). To a solution of alcohol 4 (150 mg, $0.53 \mathrm{mmol}$ ) was added NBS (95 mg, $0.53 \mathrm{mmol})$ and $\mathrm{PPh}_{3}(140 \mathrm{mg}, 2.8 \mathrm{mmol})$ in $\mathrm{CH}_{2} \mathrm{Cl}_{2}(10 \mathrm{~mL})$. The mixture was stirred for $10 \mathrm{~min}$ at rt. The reaction was quenched with saturated aqueous $\mathrm{NaHCO}_{3}(5 \mathrm{~mL})$ and extracted with EtOAc. The organic layer was washed with brine, dried over $\mathrm{MgSO}_{4}$, filtered, and concentrated. The residue was purified by silica gel column chromatography (hexane : AcOEt = $50: 1)$ to give crude 6 (160 mg, 92\%) as a colorless oil. This compound was immediately used for the next step without further purification. IR (film) $v_{\max } \mathrm{cm}^{-1}: 2923,2852,1465,963$; ${ }^{1} \mathrm{H}$ NMR (500 MHz, CDCl $)_{3}$ ) $\delta=0.88$ (3H, t, $\left.J=6.9 \mathrm{~Hz}\right), 1.20-1.30$ (32H, m), 1.34-1.39 (2H, m), 2.03-2.07 (2H, m), 3.95 (2H, d, $J=7.4 \mathrm{~Hz}$ ), 5.66-5.79 (2H, m); ${ }^{13} \mathrm{C}$ NMR (125 MHz, $\mathrm{CDCl}_{3}$ ) $\delta: 14.09,22.68,29.11,29.35,29.44$, 29.57, 29.64, 29.66, 29.66, 29.69, 31.93, 32.06, 33.59, 126.26, 136.79.

4.1.4. (2S, 3S)-1, 2-Epoxynonadecan-3-ol (7a). To a suspension of AD mix $\alpha$ (690 mg) in $t$-BuOH/ $\mathrm{H}_{2} \mathrm{O}(1 / 1)$ (10 mL) was added allyl bromide (160 mg, $0.49 \mathrm{mmol}$ ) and $\mathrm{MeSO}_{2} \mathrm{NH}_{2}(47 \mathrm{mg}, 0.49 \mathrm{mmol}$ ). The mixture was stirred for $16 \mathrm{~h}$ at $0{ }^{\circ} \mathrm{C}$. The reaction was quenched with aqueous $\mathrm{Na}_{2} \mathrm{SO}_{3}(5 \mathrm{~mL})$ and extracted with EtOAc. The organic layer was washed with brine, dried over $\mathrm{MgSO}_{4}$, filtered, and concentrated. The residue was purified by silica gel column chromatography (hexane : AcOEt = $5: 1$ ) to give 7a (100 mg, 74\%) as a colorless solid. Mp 61$63{ }^{\circ} \mathrm{C} ;[\alpha]_{\mathrm{D}}^{18}=-0.17$ (c 0.50, $\left.\mathrm{CHCl}_{3}\right)$; IR $(\mathrm{KBr}) v_{\max } \mathrm{cm}^{-1}$ : 3344, 2954, 2916, 2848, 1466, 1125, 962, 868, 755, 720; ${ }^{1} \mathrm{H}$ NMR (500 MHz, $\mathrm{CDCl}_{3}$ ): $\delta=0.88$ (3H, t, $J=6.9 \mathrm{~Hz}$ ), 1.20-1.30 (26H, m), 1.37-1.41 (2H, m), 1.58-1.63 (2H, m), $1.73(1 \mathrm{H}, \mathrm{d}, J=6.0 \mathrm{~Hz}), 2.72(1 \mathrm{H}, \mathrm{dd}, J=2.8,4.9 \mathrm{~Hz}), 2.82(1 \mathrm{H}, \mathrm{dd}, J=4.1,4.9 \mathrm{~Hz}), 2.98$ (1H, ddd, $J$ = 2.8, 4.1, $4.9 \mathrm{~Hz}), 3.44(1 \mathrm{H}, \mathrm{m}) ;{ }^{13} \mathrm{C} \mathrm{NMR}\left(125 \mathrm{MHz}, \mathrm{CDCl}_{3}\right) \delta: 14.09,22.68,25.35,29.35,29.53,29.57,29.60$, 29.66, 29.69, 31.92, 34.49, 55.31, 71.64; HRFABMS [(M+H) ${ }^{+}$]: calcd. for $\mathrm{C}_{19} \mathrm{H}_{39} \mathrm{O}_{2}$, 299.2950; found 299.2941.

4.1.5. (2S,3S)-1, 2-Epoxy-3-methoxymethoxynonadecane (8a). To a solution of alcohol 7a (50 mg, $0.18 \mathrm{mmol})$ and $i-\mathrm{Pr}_{2} \mathrm{NEt}(0.045 \mathrm{~mL}, 0.27 \mathrm{mmol})$ in $\mathrm{CH}_{2} \mathrm{Cl}_{2}(1.0 \mathrm{ml})$ was added $\mathrm{MOMBr}(0.02 \mathrm{~mL}, 0.23 \mathrm{mmol})$ at $0{ }^{\circ} \mathrm{C}$. The mixture was stirred for $12 \mathrm{~h}$ at rt. The reaction was quenched with saturated aqueous $\mathrm{NH}_{4} \mathrm{Cl}(2.0 \mathrm{~mL})$ and extracted with EtOAc. The organic layer was washed with brine, dried over $\mathrm{MgSO}_{4}$, filtered, and concentrated. The residue was purified by silica gel column chromatography (hexane : AcOEt =10 : 1) to give $8 a$ (55 mg, 91\%) 
as a colorless oil. $[\alpha]_{D}^{20}=-24.2\left(c\right.$ 1.70, $\left.\mathrm{CHCl}_{3}\right)$; IR (film) $v_{\max } \mathrm{cm}^{-1}: 3046,2925,2853,1467,1401,1377,1257$, 1216, 1152, 1102, 1036, 920, 848, 811, 721; ${ }^{1} \mathrm{H}$ NMR (500 MHz, $\mathrm{CDCl}_{3}$ ): $\delta=0.88$ (3H, t, $\left.J=6.9 \mathrm{~Hz}\right), 1.20-1.30$ (24H, m), 1.36-1.43 (2H, m), 1.46-1.52 (2H, m), 1.55-1.64 (2H, m), 2.53 (1H, dd, J = 2.7, $4.9 \mathrm{~Hz}), 2.77$ (1H, dd, $J=4.3,4.7 \mathrm{~Hz}$ ), 2.96-2.99 (1H, m), 3.26 (1H, dd, $J=7.2,12.8 \mathrm{~Hz}), 3.40$ (3H, s), 4.67 (1H, d, $J=6.7 \mathrm{~Hz}), 4.87$ $(1 \mathrm{H}, \mathrm{d}, J=6.7 \mathrm{~Hz}) ;{ }^{13} \mathrm{C} \mathrm{NMR}\left(125 \mathrm{MHz}, \mathrm{CDCl}_{3}\right) \delta: 14.09$, 22.68, 25.44, 29.35, 29.52, 29.58, 29.65, 29.69, 31.92, 32.32, 43.84, 54.70, 55.57, 78.01, 95.54; HRFABMS [(M+H) $\left.{ }^{+}\right]$: calcd. for $\mathrm{C}_{21} \mathrm{H}_{43} \mathrm{O}_{3}$, 343.3212; found, 343.3207 .

4.1.6. (3S, 4S)-5-methoxymethoxy-1-docosyn-4-ol (9a). To a suspension of lithium acetylide, an ethylene diamine complex (34 mg, $0.17 \mathrm{mmol}$ ) in DMSO (1.0 mL) was added epoxide 8a (22 mg, $0.066 \mathrm{mmol})$ in DMSO $(0.20 \mathrm{~mL})$ at $0{ }^{\circ} \mathrm{C}$. The mixture was stirred for $12 \mathrm{~h}$ at rt. The reaction was quenched with saturated aqueous $\mathrm{NH}_{4} \mathrm{Cl}(1.0 \mathrm{~mL})$. The resulting mixture was extracted with EtOAc. The organic layer was washed with brine, dried over $\mathrm{MgSO}_{4}$, filtered, and concentrated. The residue was purified by silica gel column chromatography (hexane : AcOEt $=10: 1)$ to give 9a $(22 \mathrm{mg}, 95 \%)$ as a colorless oil. $[\alpha]^{20}{ }_{\mathrm{D}}=+18.2,\left(c 0.74, \mathrm{CHCl}_{3}\right)$; IR (film) $v_{\max } \mathrm{Cm}^{-1}: 3445,3312,2920,2851,1467,1377,1257,1213,1150,1100,1037,920,721,636 ;{ }^{1} \mathrm{H}$ NMR (500 $\left.\mathrm{MHz}, \mathrm{CDCl}_{3}\right): \delta=0.88(3 \mathrm{H}, \mathrm{t}, J=6.9 \mathrm{~Hz}), 1.20-1.30(24 \mathrm{H}, \mathrm{m}), 1.33-1.48(4 \mathrm{H}, \mathrm{m}), 1.48-1.54(1 \mathrm{H}, \mathrm{m}), 1.58-1.64$ (1H, m), 2.02 (1H, t, $J=2.7 \mathrm{~Hz}), 2.42$ (1H, ddd, $J=2.7,6.3,16.8 \mathrm{~Hz}), 2.49$ (1H, ddd, $J=2.7,5.8,16.8 \mathrm{~Hz}), 2.90$ $(1 \mathrm{H}, \mathrm{d}, J=5.6 \mathrm{~Hz}), 3.40$ (3H, s), 3.58-3.62 (1H, m), 3.69-3.73 $(1 \mathrm{H}, \mathrm{m}), 4.70(1 \mathrm{H}, \mathrm{d}, J=6.8 \mathrm{~Hz}), 4.72(1 \mathrm{H}, \mathrm{d}, J=$ $6.8 \mathrm{~Hz}) ;{ }^{13} \mathrm{C}$ NMR $\left(125 \mathrm{MHz}, \mathrm{CDCl}_{3}\right) \delta: 14.07,22.66,23.65,25.26,29.54,29.57,29.64,29.65,29.67,30.92$, 31.91, 55.87, 70.26, 71.11, 80.73, 81.15, 97.01; HREIMS (M) ${ }^{+}$: calcd. for $\mathrm{C}_{23} \mathrm{H}_{44} \mathrm{O}_{3}$, 368.3290; found, 368.3307.

4.1.7. (EZ, 3RS, 5S, 15'S, 16'S)-3-(15'-Hydroxy-16'-methoxymethoxy- 10'-ditriaconten-12'-ynyl)-5-methyl2, 5-dihydrofuran-2-one (11a). To a solution of lactone 10 (12 mg, $0.031 \mathrm{mmol})$ in $\mathrm{Et}_{3} \mathrm{~N}(1.0 \mathrm{~mL})$ was added $\mathrm{Cl}_{2} \mathrm{Pd}\left(\mathrm{PPh}_{3}\right)_{2}$ (1.3 mg, $\left.0.0031 \mathrm{mmol}\right)$. After being stirred for $60 \mathrm{~min}$, a solution of 9a (11 mg, $\left.0.031 \mathrm{mmol}\right)$ in $\mathrm{Et}_{3} \mathrm{~N}(2.0 \mathrm{~mL})$ and $\mathrm{CuI}(0.6 \mathrm{mg}, 0.0031 \mathrm{mmol})$ were added to the solution. After being stirred for $12 \mathrm{~h}$, the reaction was quenched with saturated $\mathrm{NH}_{4} \mathrm{Cl}(1 \mathrm{~mL})$ and the mixture was extracted with diethyl ether. The organic phase was washed with brine, dried over $\mathrm{MgSO}_{4}$, filtered, and concentrated. The residue was purified by silica gel column chromatography (hexane : AcOEt $=5: 1$ ) to give 11a (13 mg, 65\%) as a colorless oil. IR (film) $v_{\max } \mathrm{Cm}^{-1}$ : 3466, 2925, 28531, 1759, 1466, 1373, 1318, 1202, 1149, 1101, 1032, 954, 920, 722; ${ }^{1} \mathrm{H}$ NMR (500 $\left.\mathrm{MHz} \mathrm{CDCl}_{3}\right): \delta=0.88(3 \mathrm{H}, \mathrm{t}, J=6.7 \mathrm{~Hz}), 1.20-1.40(40 \mathrm{H}, \mathrm{m}), 1.41(3 \mathrm{H}, \mathrm{d}, J=6.8 \mathrm{~Hz}), 1.45-1.67(4 \mathrm{H}, \mathrm{m}), 2.07$ (1H, t, $J=7.0 \mathrm{~Hz}), 2.25-2.30$ (3H, m), 2.50-2.67 (2H, m), 2.86-2.88 (1H, m), $3.42(3 \mathrm{H}, \mathrm{s}), 3.55-3.64$ (1H, m), 3.70-3.74 (1H, m), 4.70 (1H, d, $J=6.8 \mathrm{~Hz}), 4.72(1 \mathrm{H}, \mathrm{d}, J=6.8 \mathrm{~Hz}), 5.00$ (1H, dq, $J=1.4,6.8 \mathrm{~Hz}), 5.42-5.46$ $(1 \mathrm{H}, \mathrm{m}), 5.84(0.6 \mathrm{H}, \mathrm{dt}, J=10.7,7.0 \mathrm{~Hz}), 6.07(0.4 \mathrm{H}, \mathrm{dt}, J=15.8,7.3 \mathrm{~Hz}), 6.99(1 \mathrm{H}, \mathrm{d}, J=1.4 \mathrm{~Hz}) ;{ }^{13} \mathrm{C} \mathrm{NMR}$

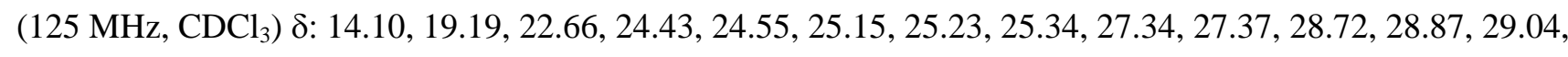
29.13, 29.25, 29.29, 29.34, 29.39, 29.44, 29.46, 29.56, 29.60, 29.63, 29.68, 29.72, 30.19, 30.86, 30.93, 31.89, 32.94, 55.84, 71.06, 71.31, 71.35, 79.63, 81.13, 81.15, 81.19, 81.26, 84.24, 89.93, 96.96, 108.96, 109.44, 134.27, 143.27, 144.16, 148.84, 173.89; HRFABMS [(M+Na) ${ }^{+}$: calcd. for $\mathrm{C}_{39} \mathrm{H}_{68} \mathrm{O}_{5} \mathrm{Na}$, 639.4964; found, 639.4980.

\subsection{8. (3RS, 5S, 15'S, 16'S)-3-(15'-Hydroxy-16'-methoxymethoxy-yditriacontyl)-5-methyl-2, 5-}

dihydrofuran-2-one (12a). To a refluxing solution of $11 \mathbf{a}(13 \mathrm{mg}, 0.020 \mathrm{mmol})$ and $p$-toluenesulfonylhydrazide 
(270 mg, $1.4 \mathrm{mmol})$ in diethoxyethane $(1.0 \mathrm{~mL})$ was added a solution of sodium acetate $(140 \mathrm{mg}, 1.7 \mathrm{mmol})$ in $\mathrm{H}_{2} \mathrm{O}$ (3.0 mL) over a period of $4 \mathrm{~h}$. After being cooled to room temperature, the mixture was extracted with diethyl ether. The organic phase was washed with brine, dried over $\mathrm{MgSO}_{4}$, filtered, and concentrated. The residue was purified by silica gel column chromatography (hexane : AcOEt $=5: 1$ ) to give 12a (8.0 mg, 64\%) as a colorless solid. $\mathrm{Mp} 38-40^{\circ} \mathrm{C}$; $[\alpha]^{18}{ }_{\mathrm{D}}=+17$ (c 0.16, $\left.\mathrm{CHCl}_{3}\right)$; IR $(\mathrm{KBr}) v_{\max } \mathrm{cm}^{-1}$ : 3488, 2924, 2853, 1759, 1466, 1373, 1318, 1200, 1147, 1099, 1035, 951, 919, 721; ${ }^{1} \mathrm{H}$ NMR (500 MHz, $\left.\mathrm{CDCl}_{3}\right): \delta=0.88(3 \mathrm{H}, \mathrm{t}, J=6.9 \mathrm{~Hz})$, 1.20-1.40 (48H, m), 1.41 (3H, d, $J=6.8 \mathrm{~Hz}), 1.42-1.63(8 \mathrm{H}, \mathrm{m}), 2.26(2 \mathrm{H}, \mathrm{tt}, J=1.6,7.7 \mathrm{~Hz}), 2.76(1 \mathrm{H}, \mathrm{d}, J=$ $4.1 \mathrm{~Hz}), 3.34(1 \mathrm{H}, \mathrm{m}), 3.42$ (3H, s), $3.50(1 \mathrm{H}, \mathrm{m}), 4.70(1 \mathrm{H}, \mathrm{d}, J=6.8 \mathrm{~Hz}), 4.72(1 \mathrm{H}, \mathrm{d}, J=6.8 \mathrm{~Hz}), 5.00$ (1H, qd, $J=6.8,1.5 \mathrm{~Hz}), 6.99(1 \mathrm{H}, \mathrm{d}, J=1.5 \mathrm{~Hz}) ;{ }^{13} \mathrm{C} \mathrm{NMR}\left(125 \mathrm{MHz}, \mathrm{CDCl}_{3}\right) \delta: 14.12,19.20,22.68,25.16,25.62$, 27.37, 29.17, 29.31, 29.35, 29.52, 29.57, 29.59, 29.62, 29.64, 29.69, 29.75, 29.79, 31.91, 33.29, 55.83, 72.74, 77.41, 83.45, 97.08, 134.31, 148.84, 173.92; HRFABMS [(M+Na) ${ }^{+}$]: calcd. for $\mathrm{C}_{39} \mathrm{H}_{74} \mathrm{O}_{5} \mathrm{Na}, 645.5434$; found, 645.5426 .

4.1.9. (17S, 18S)-Tonkinelin (1a). To a solution of 12a (8.0 mg, $0.012 \mathrm{mmol})$ in dimethyl sulfide (1.0 mL) was added $\mathrm{BF}_{3} \cdot \mathrm{Et}_{2} \mathrm{O}(0.10 \mathrm{~mL}, 1.0 \mathrm{mmol})$ at $0{ }^{\circ} \mathrm{C}$. After being stirred for $1 \mathrm{~h}$ at this temperature, the reaction was quenched with saturated $\mathrm{NaHCO}_{3}(1.0 \mathrm{~mL})$ and the mixture was extracted with AcOEt. The organic phase was washed brine, dried over $\mathrm{MgSO}_{4}$, filtered, and concentrated. The residue was purified by silica gel column chromatography (hexane : AcOEt $=2: 1$ ) to give 1a $(4.0 \mathrm{mg}, 6.9 \mu \mathrm{mol}, 56 \%)$ as a colorless solid. $\mathrm{Mp} 73-76{ }^{\circ} \mathrm{C}$; $[\alpha]_{\mathrm{D}}^{18}=+11.6$ (c 0.14, $\left.\mathrm{CHCl}_{3}\right)$; IR (KBr) $v_{\max } \mathrm{cm}^{-1}$ : 3234, 2915, 2847, 1741, 1465, 1322, 1066, 1022, 720; ${ }^{1} \mathrm{H}-$ NMR (500 MHz, CDCl $): \delta=0.88(3 \mathrm{H}, \mathrm{t}, J=6.9 \mathrm{~Hz}), 1.20-1.40(52 \mathrm{H}, \mathrm{m}), 1.41(3 \mathrm{H}, \mathrm{d}, J=6.8 \mathrm{~Hz}), 1.43-1.58$ (4H, m), 2.01 (2H, br.), 2.27 (2H, t, $J=7.8 \mathrm{~Hz}$ ), 3.41 (2H, m), 5.00 (1H, qd, $J=6.8,1.5 \mathrm{~Hz}), 6.99$ (1H, d, $J=1.5$ $\mathrm{Hz}) ;{ }^{13} \mathrm{C}$ NMR (125MHz, $\left.\mathrm{CDCl}_{3}\right) \delta: 14.13,19.21,22.69,25.16,25.65,27.38,29.17,29.29,29.36,29.50,29.59$, 29.60, 29.62, 29.65, 29.67, 29.69, 31.92, 33.59, 74.53, 77.43, 134.31, 148.87, 173.96; HRFABMS [(M+H) $\left.{ }^{+}\right]$: calcd. for $\mathrm{C}_{37} \mathrm{H}_{71} \mathrm{O}_{4}, 579.5352$; found, 579.5359 .

4.1.10. (17R, 18R)-Tonkinelin (1b). $\mathrm{Mp} 77-79{ }^{\circ} \mathrm{C} ;[\alpha]_{\mathrm{D}}^{18}=+0.80\left(c 0.20, \mathrm{CHCl}_{3}\right)$; IR (KBr) $v_{\max } \mathrm{Cm}^{-1}: 3234$, 2915, 2847, 1741, 1465, 1322, 1066, 1022, 720; ${ }^{1} \mathrm{H}$ NMR (500 MHz, $\left.\mathrm{CDCl}_{3}\right): \delta=0.88$ (3H, t, $\left.J=6.9 \mathrm{~Hz}\right), 1.20-$ 1.40 (52H, m), 1.41 (3H, d, $J=6.8$ Hz), 1.43-1.58 (4H, m), 2.01 (2H, br.), 2.27 (2H, t, $J=7.8 \mathrm{~Hz}), 3.41$ (2H, m), $5.00(1 \mathrm{H}, \mathrm{qd}, J=6.8,1.6 \mathrm{~Hz}), 6.99(1 \mathrm{H}, \mathrm{d}, J=1.6 \mathrm{~Hz}) ;{ }^{13} \mathrm{C}-\mathrm{NMR}\left(125 \mathrm{MHz}, \mathrm{CDCl}_{3}\right) \delta: 14.09,19.22,22.68$, 25.19, 25.66, 27.43, 29.18, 29.30, 29.35, 29.51, 29.59, 29.61, 29.63, 29.66, 29.69, 31.93, 33.68, 74.55, 77.36, 134.41, 148.78, 173.85; HRFABMS [(M+H) $\left.{ }^{+}\right]$: calcd. for $\mathrm{C}_{37} \mathrm{H}_{71} \mathrm{O}_{4}, 579.5352$; found, 579.5344 .

4.2. Biochemical Methods. Bovine heart submitochondrial particles were prepared by the method of MatsunoYagi and Hatefi ${ }^{15}$ and stored in a buffer containing $0.25 \mathrm{M}$ sucrose and $10 \mathrm{mM}$ Tris- $\mathrm{HCl}(\mathrm{pH} 7.4)$ at $-82{ }^{\circ} \mathrm{C}$. The NADH oxidase activity in the particles was followed spectrometrically with a Shimadzu UV-3000 (340 nm, $\varepsilon=$ $\left.6.2 \mathrm{mM}^{-1} \mathrm{~cm}^{-1}\right)$ at $30{ }^{\circ} \mathrm{C}$. The reaction medium $(2.5 \mathrm{~mL})$ contained $0.25 \mathrm{M}$ sucrose, $1 \mathrm{mM} \mathrm{MgCl}_{2}$ and $50 \mathrm{mM}$ phosphate buffer ( $\mathrm{pH}$ 7.4). The final mitochondrial protein concentration was $30 \mu \mathrm{g}$ of protein $/ \mathrm{mL}$. The reaction 
was started by adding $50 \mu \mathrm{M}$ NADH after the equilibration of the particles with inhibitor for $5 \mathrm{~min}$. The $\mathrm{IC}_{50}$ values were averaged from three independent experiments.

\section{References and notes}

1. Bermejo, A.; Figadére, B.; Zafra-Polo, M. -C.; Barrachina, I.; Estornell, E.; Cortes, B. L. Nat. Prod. Rep. 2005, 22, 269-303.

2. Alali, F. Q.; Liu, X. -X.; McLaughlin, J. L. J. Nat. Prod. 1999, 62, 504-540.

3. Zafra-Polo, M. C.; Figadère, B.; Gallardo, T.; Tormo, J. R.; Cortes, D. Phytochemistry 1998, 48, 1087-1117.

4. Abe, M.; Murai, M.; Ichimaru, N.; Kenmochi, A.; Yoshida, T.; Kubo, A.; Kimura, Y.; Moroda, A.; Makabe, H.; Nishioka, T.; Miyoshi, H. Biochemistry 2005, 44, 14898-14906.

5. For recent syntheses of annonaceous acetogenins: (a) Curran, D. P.; Zhang, Q.; Richard, C.; Lu, H.; Gudipati, V.; Wilcox, C. S. J. Am. Chem. Soc. 2006, 128, 9561-9573. (b) Göksel, H.; Stark, B. W. Org. Lett. 2006, 8, 3433-3436. (c) Hattori, Y.; Kimura, Y.; Moroda, A.; Konno, H.; Abe, M.; Miyoshi, H.; Goto, T.; Makabe, H. Chem. Asian. J. 2006, 1, 894-904. (d) Narayan, R. S.; Borhan, B. J. Org. Chem. 2006, 71, 1416-1429. (e) Tominaga, H.; Maezaki, N.; Yanai, M.; Kojima, N.; Urabe, D.; Ueki, R.; Tanaka, T. Eur. J. Org. Chem. 2006, 1422-1429. (f) Marshall, J. A.; Sabatini, J. J. Org. Lett. 2006, 8, 3557-3560. (g) Zhao, H.; Gorman, J. S. T.; Pagenkopf, B. Org. Lett. 2006, 8, 4379-4382. (h) Strand, D.; Norrby, P. -O.; Rein, T. J. Org. Chem. 2006, 71, 1879-1891. (i) Crimmins, M. T.; Zhang, Y.; Diaz, F. A. Org. Lett. 2006, 8, 2369-2372. (i) Hoye, T. R.; Eklov, B. M.; Jeon, J.; Khoroosi, M. Org. Lett. 2006, 8, 3383-3386. (k) Bandur, N. G.; Brückner, D.; Hoffmann, R. W.; Koert, U. Org. Lett. 2006, 8, 3829-3831. (l) Takahashi, T.; Hongo, Y.; Ogawa, N.; Koshino, H.; Nakata, T. J. Org. Chem. 2006, 71, 6305-6308. (m) Donohoe, T. J.; Harris, R. M.; Burrows, J.; Parker, J. J. Am. Chem. Soc. 2006, 128, 13704-13705. (n) Makabe, H.; Kimura, Y.; Higuchi, M.; Konno, H.; Murai, M.; Miyoshi, H. Bioorg. Med. Chem. 2006, 14, 3119-3130.

6. Chen, Y.; Yu, D. Q. Planta Med. 1996, 62, 512-514.

7. Hoye, T. R.; Hanson, P. R.; Hasenwinkel, L. E.; Ramirez, E. A.; Zhuang, Z. P. Tetrahedron Lett. 1994, 35, 8529-8532.

8. Curran, D. P.; Zhang, Q., Lu, H.; Gudipati, V. J. Am. Chem. Soc. 2006, 128, 9943-9956.

9. Kolb, H. C.; VanNieuwenhze, M. S.; Sharpless, K. B. Chem. Rev. 1994, 94, 2483-2547.

10. Makabe, H.; Miyawaki, A.; Takahashi, R.; Hattori, Y.; Konno, H.; Abe, M.; Miyoshi, H. Tetrahedron Lett. 2004, 45, 973-977.

11. Sonogashira, K.; Tohda, Y.; and Hagihara, N. Tetarhedron Lett. 1975, 16, 4467-4470. 
12. Miyoshi, H.; Ohshima, M.; Shimada, H.; Akagi, T.; Iwamura, H.; McLaughlin, J. L. Biochim. Biophys. Acta 1998, $1365,443-452$.

13. Makabe, H.; Hattori, Y.; Kimura, Y.; Konno, H.; Abe, M.; Miyoshi, H.; Tanaka, A.; Oritani, T. Tetrahedron 2004, 60, 10651-10657.

14. Konno, H.; Hiura, N.; Makabe, H.; Abe, M.; Miyoshi, H. Bioorg. Med. Chem. Lett. 2004, 14, 629-632.

15. Matsuno-Yagi, A.; Hatefi, Y. J. Biol. Chem. 1985, 260, 14424-14427. 